\title{
WHAT IF OUR BELOVED CHILDREN ARE ADDOCTED TO PHONESEX?
}

\author{
Mochamad Soelton, Tati Nugrahati, Noermijati, Nico Alexander-Vizano, and Rajab Ritonga \\ Universitas Mercu Buana Jakarta, Indonesia \\ Universitas Brawijaya, Indonesia \\ Universitas Prof. Dr. Moestopo (Beragama), Indonesia \\ soeltonibrahem@gmail.com
}

\begin{abstract}
Adolescence is a time of rapid changes in the process of physical, cognitive and psychosocial or behavioral and hormonal growth. At the age of adolescence, namely the age range of 15 to 18 years adolescents will experience the first puberty, even some children experience puberty more quickly, which is around 10-13 years. In puberty, there is a strong urge that comes from within the individual to know something that he had never known. Circumstances like this that encourage adolescents in this case to try new things in life, including free sex (free sex). Sexual activity via mobile phones has now mushroomed in the community. Do not know the beginning of when it began, but certainly there are many who know if sex can be done via cellular phone. The activity of having sex through a cellular phone is called phone sex. Telephone sex (Phone Sex) is a type of virtual sex that refers more to explicit sexual conversations that occur between two or more people over the telephone especially when one participant or sex partner masturbates or performs sexual fantasies. Phone Sex (PS) is a sexual activity carried out by listening on a cellular phone. Providing sex education for children is the responsibility of all parties: parents, teachers, the community and the government. It becomes a preventive measure that can be applied early, by providing sex education for their children, especially in Early Childhood Education
\end{abstract}

Keywords: Cellular Phone, Early Childhood, Phone Sex, Parents, Sex Education

\section{INTRODUCTION}

From the survey of adolescent reproductive health, adolescent Indonesia first $\mathbf{k}$ ali dating at the age of 12 years. Adolescent courtship behavior is also increasingly permissive, as many as $92 \%$ of adolescents hold hands when dating, $82 \%$ kiss, $63 \%$ petting palpation. These behaviors then trigger teenagers to have sexual relations (KPAI, 2012). The Center for Criminology Studies at the Islamic University of Indonesia in Yogyakarta found that $26.35 \%$ of 846 marital incidents had sexual relations before marriage, of which $50 \%$ caused pregnancy. Based on the BKKBN survey (2011), in Indonesia 63 million adolescents aged 10-24 years are behaving unhealthily about premarital sex. Thus increasing the incidence of abortion among adolescents, obtained 2.6 million people per year and of the total $27 \%$ or 70,000 among teenagers having an abortion. Statistics about the deviation (deviation) of premarital free sex behavior of adolescents in Indonesia from year to year is increasingly large.

In the era of 1970, research on premarital free sexual behavior showed a figure of 7-9\%. Decade in 1980 , that number increased to $12-15 \%$. Next in 1990 increased again to $20 \%$. In the current era, the Center for Criminology Studies at the Islamic University of Indonesia in Yogyakarta found that 26.35\% of the 846 marriages had premarital sexual relations, of which $50 \%$ caused pregnancy. Judging from the results of the data above, teenage behavior is now very worrying. This is indicated by the increasing number of cases such as abortion, unwanted pregnancy (KTD), and sexually transmitted infections (STIs) including HIV / AIDS. Cases that occur not only occur in adolescent girls, but also adolescent boys. Many factors cause the case. One of the factors such as knowledge gained from sharing media one of which is a mobile phone (HP). Sex activities via mobile (phonesex). Resulting in many teenagers who do deviant behavior in the use of mobile phones. Adolescence or puberty is a period of changing attitudes and behaviors from childhood to young adulthood.

Adolescence is a time of rapid changes in the process of physical, cognitive and psychosocial or behavioral and hormonal growth. At the age of adolescence, namely the age range of 15 to 18 years adolescents will experience the first puberty, even some children experience puberty more quickly, which is around 10-13 years. In puberty, there is a strong urge that comes from within the individual to know something that he had never known. Circumstances like this that encourage adolescents in this case to try new things in life, including free sex (free sex). Sexual activity via mobile phones has now mushroomed in the community. Do not know the beginning of when it began, but certainly there are many who know if sex can be done via cellular phone. The activity of having sex through a cellular phone is called phone sex. Telephone sex (Phone Sex) is a type of 
virtual sex that refers more to explicit sexual conversations that occur between two or more people over the telephone especially when one participant or sex partner masturbates or performs sexual fantasies. Phone Sex (PS) is a sexual activity carried out by listening on a cellular phone.

The existence of sophisticated and modern technology is deliberately created by humans to make it easier to do work and access all information and knowledge, so that in their work humans can complete it in a short time. No matter how wide the distance humans can easily access various kinds of information in this part of the world. The increasingly intensive information flow across the world has inevitably changed the views and sexual behavior of Indonesian youth, resulting in deviations that have led to increasingly waning norms in society. . To reduce this incident, prevention programs can be carried out such as holding counseling about the impact arising from the phenomenon of phone sex so as to prevent free sex (free sex) among adolescents.

Teenagers have exchanged photos that are not good with their girlfriends, other teenagers often talk via telephone or video call and talk about things that smelled of sex even among those who did masturbation to vent their satisfaction. And the teenager had watched and even exchanged sex videos with girlfriends and friends. So I participated in conducting counseling with the theme "He Is Our Heart (Protect Teenagers, Don't Let the Nation Shoots Damaged Instantly) By Socializing the Impact of Phone Sex To Prevent Free Sex in Teens in the P almerah area.

Reproductive health education is very important for the prevention of sexual risk behaviors and their negative effects unwanted pregnancy outcomes, HIV / AIDS, and other sexually transmitted infections (STIs) in adolescents. Young people receive reproductive health education from a variety of sources, including formal education (eg, Schools) and informal education (eg, parents, peers, and the media) (L'Engle, Brown, \& Kenneavy, 2006; Kirby, 1999; 2002; Canadian Public Health Agency, 2008). Positive youth development strategies that promote general development skills have been seen as alternatives to approaches that promote adolescent health by only focusing on risk factors (American College of Obstetricians and Gynecologists, 2006). More and more research is stressing the importance of understanding the role that promotive and / or protective factors play a role in reducing negative health outcomes for adolescents, including adolescent sexual and reproductive health outcomes (Abma, Martinez, Mosher, \& Dawson, 2004; Rangel, Gavin, Reed, Fowler, \& Lee, 2006).

It is important to guide the growth and development of a quality generation since childhood. Every individual, during their lifetime, needs to achieve developmental tasks in each period (Havigurst in Hurlock, Istiwidayanti, Sijabat, \& Soedjarwo, 2009). However, many education problems are still not finished. Problems always arise and need attention and involvement of all parties. One problem that needs serious attention is sex education for children. This is related to the increase in cases of immoral behavior such as free sex, sexual harassment, sexual immorality, and even student age pregnancies caused by the very lack of sex education that they get. The argument is supported by a lot of opinions and research findings that $\mathrm{d}$ ijelaskan by Blackburn (2009) knowledge about sex is needed to protect to health is the adolescent reproductive organs Young people should protect themselves from misinformation about sex.

Another opinion shows that sex education is an important thing to give to individuals since their childhood as a preventive measure of immoral behavior happening now. This is also supported by Havigurst (Hurlock et al., 2009) that the development tasks that should be achieved by children during their childhood because in this period is to learn about gender. The understanding that a minimum of sex education gives harmful effects on children's deviant sexual behavior. This is the same as said by Zenik \& KIM (Wirawan, 200 7) that adolescents who receive sex education will not tend to have sexual intercourse, sexual intercourse more frequently than those who do not understand sex education that leads them to experience pregnancy diinginka $n$. Therefore, children without sex education will be higher in the percentage of engaging in immoral behavior such as free sexual relations, while children with sex education are in a lower percentage in engaging in unethical behavior.

Providing sex education for children is the responsibility of all parties: parents, teachers, the community and the government. It is a preventive measure that can be applied early, by providing sex education for their children, especially in Early Childhood Education or Kindergarten Schools. Early Childhood Education Teachers are pioneers in starting sex education in Indonesia at the lowest education level.

The family as a cell only acts with love and respect and dominates understanding, affection, child sacrifice and parenting. (Emerllahu, Dali, 2001) So, in this way building a family environment, where we live, laugh, play, and develop children. (Claudia \& Eberhard Muhlan. 2008). Parents take an important attitude, when it comes to the development and education of their children as a whole, as parents themselves are people who care for children as a whole both physical and intellectual development, insofar as they are independent and ready to face the challenges of the community where they live 


\section{IMPLEMENTATION METHOD}

Problem solving is done by conducting a direct assessment of adolescents aged 14-17 years for 1 day by conducting interviews about the level of knowledge about phone sex (understanding, impact, and prevention). From the results of the assessment, a data interpretation was conducted, the need for counseling about the phenomena of phone sex among adolescents about the impact on free sex behavior. The stages are as follows :

Activity Process

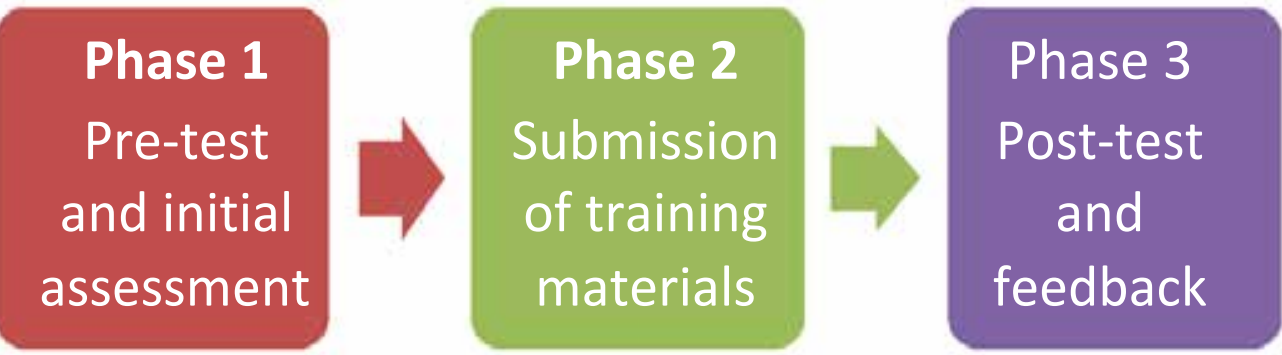

Phase 1

Spread questioners to find out what level of knowledge of adolescents about the phenomena of phone sex and the effects of dependence on phone sex. After reviewing the data, then prepare starting from the material and media that will be used in counseling. After the technical preparation is complete, after that inform the public, especially teenagers, that counseling will be held about the phenomenon of phone sex, the impact on free sex among adolescents and displaying videos related to phone sex abuse .

\section{Phase 2}

At this stage, counseling will be held to adolescents about the phenomenon of Phone sex, in this counseling is expected to increase knowledge about phone sex to behavior of sex, provide a pocket book about the impact and efforts to prevent Youth (students) Counseling about the impact of the phenomenon of phone sex on the behavior of free sex Understanding of phone sex, Understanding of free sex, Impact of phone sex Prevention of unwanted pregnancy Counseling Adolescent knowledge increases Give a pocket book about Phone sex and early marriage. So that young people in the area can be motivated to not abuse the phone or media technology and communication tools else for things that are deviant .

\section{Phase 3}

On stage will be conducted evaluations to teenagers, are expected to be able to understand to the counseling given. Teenagers not only listen but can also apply in their daily lives. And can read pocket books about the effects and efforts to prevent early marriages. So that by knowing the impact and description of events that have occurred can be a reflection for adolescents in the area so that they will not fall into the same thing. If found adolescents who are already or addicted to phone sex we will provide guidance or and will be referred to a psychologist.

\section{RESULT AND DISCUSSION}

The results obtained from this program about finding and examining the role and impact of sexual education in shaping positive sexual behavior in adolescents and the implications for adolescent psychology endurance are as follows: (1) By using family methods, effective in tackling free sex among teenagers; (2) The use of contraceptives can reduce the impact of free sex (premarital pregnancy/ early marriage ); (3) The binding of family ties will make teens think more about what will happen after free sex; (4) The role of parents is very important, children must be open to each other if there are problems or other stories to parents, so parents can monitor their children's relationship

\section{CONCLUSIONS}

Based on the discussion previously explained, the following conclusions can be drawn: (1) Several attempts were made in counseling about sex education for children and adolescents to provide good results in the context 
of protecting children and adolescents from phone sex activities; (2) Learning through counseling is expected to contribute to increasing knowledge in terms of anal and adolescent sex education.

Influential parents are important in educating children in all kinds of good or bad behavior. So as not to fall into promiscuity or free sex: (1) Families must understand about sex issues, before explaining to their children; (2) A father directs a boy and a mother directs a girl in explaining sex problems; (3) Don't explain sex to boys and girls in the same room; (4) Parents must be aware of children's relationships outside the home

\section{REFERENCES}

Abma, J.; Martinez, G.; Mosher, W.; \& Dawson, B. (2004). Teenagers in the United States: Sexual activity, contraceptive use, and childbearing, 2002. National Center for Health Statistics. Vital Health Stat 23(24):1-87. American College of Obstetricians and Gynecologists (2006). Adolescent Sexuality and Sex Education. Washington, DC: American College of Obstetricians and Gynecologists.

Badan Koordinasi Keluarga Berencana Nasional,(BKKBN 2005). Kesehatan Reproduksi Remaja. Jakarta Dianawati, Ajen. (2003). Pendidikan seks untuk remaja. Tangerang: Kawan Pustaka.

Blackburn, T. (2009). The influence of sex education on adolescent health: Abstinence-only vs. comprehensive programs. The Journal of Undergraduate Nursing Writing, 3(1), 1-10. Retrieved from http:/ftp.kumc.edu/xmlui/bitstream/ handle/2271/744/STTBlackburn.pdf?se quence=1

Damanik, Elvida, Tamrin Bangsu, and Yessilia Osira.Pengaruh Penggunaan Handphone Terhadap Perilaku Seks Remaja (Study Kasus Di Desa Sidorejo Kecamatan Pondok Kelapa Kabupaten Bengkulu Tengah Provinsi Bengkulu).

Hurlock, E. B., Istiwidayanti, Sijabat, R. M., \& Soedjarwo. (2009). Psikologi perkembangan: Suatu pendekatan sepanjang rentang kehidupan. Erlangga, Jakarta.

Kirby, D (2002), The impact of schools and school programs upon adolescent sexual behavior. The Journal of Sex Research; 39 (1):27 - 33.

Kirby, D., Laris, B.A., \& Rolleri, L. (2007). Sex and HIV education programs: Their impact on sexual behaviors of young people throughout the world. Journal of Adolescent Health, 40, 206-217.

Kirby,D. (2001). Emerging Answers: Research Findings on Programs to Reduce Teen Pregnancy. Washington, DC: National Campaign to Prevent Pregnancy.

Pinariya, Janette Maria, dan Mary Lemona. (2019). Literasi Internet Ramah Anak. Abdi Moestopo, 2(2), 50-56.

Soelton, Mochamad, Nugrahati, Tati, 2018. How Complaining Behaviors Effect on Coping Stress and Anxiety?. International Journal of Saudi Journal of Business and Management Studies (SJBMS). Vol. 3, No. 6. 623628.

Soelton et al, 2019. Gender : Stress Levels On Performance In Modern Industry. International Journal Archives of Business Research (United Kingdom). Vol. 7, No 2. 72-81

Soelton. M, Ramli. Y, Nugrahati. T, Permana. D, “TOWARD THE BEST STRATEGY IN MINIMIZING THE SPREAD OF DRUG USERS”. ICCD (International Conference on Community Development), 1 (1), 2018, 171-176 E-ISSN 2622-5611

Wirawan, S. (1997). Psikologi Remaja. Jakarta: PT. RajaGrafindo Persada. Zahrulianingdyah, A. (2015). Reproductive health education model in early childhood through education film "Damar Wulan." Journal of Education and Practice, 6(19), 184-189. Retrieved from http://www.iiste.org/Journals/index.ph p/JEP/article/view/24180

Wight, D. (2011). The effectiveness of school based sex education: what do rigorous evaluations in Britain tell us? Education and Health, 29(4), 67-73. 